\title{
ФЕРМЕНТАЦИОННЫЕ ПРОЦЕССЫ В СЕНАЖЕ ИЗ ЛЮЦЕРНЫ БЕЗ ДОБАВОК И С ИНТРОДУКЦИЕЙ ШТАММА Lactobacillus plantarum
}

\author{
Ю.А. ПОБЕДНОВ 1 , А.А. МАМАЕВ1, М.С. ШИРОКОРЯД1, Е.А. ЙЫЛДЫРЫМ $2 \bowtie$, \\ Г.Ю. ЛАПТЕВ 2 , Л.А. ИЛЬИНА ${ }^{2}$ Е.А. БРАЖНИК ${ }^{2}$, Н.В. ТАРЛАВИН 2
}

Оптимальный рН, необходимый для функционирования протеаз у люцерны, более низкий, нежели у клевера лугового или злаковых трав, а в составе этой культуры много белка и пектина, что не способствует получению качественного корма. Подкисление сенажируемой люцерны рекомендуется ускорять за счет внесения препаратов молочнокислых бактерий. В настоящей работе впервые в России было выявлено разнообразие состава микроорганизмов при ферментации сенажа с применением NGS-секвенирования. Целью работы было изучение особенностей ферментации люцерны при ее обычном сенажировании и применении препарата молочнокислых бактерий Биотроф. Опыты проводили в 2018-2019 годах. В первом опыте исследовали особенности биохимических и микробиологических процессов, возникающих при сенажировании люцерны. В качестве сырья использовали люцерну изменчивую Medicago sativa L. nothosubsp. varia (Martyn) Arcang сорта Пастбищная 88 (экспериментальное поле ФНЦ кормопроизводства и агроэкологии им. В.Р. Вильямса, Московская обл.). Перед закладкой в стеклянные бутыли объемом 0,5 л люцерну подвяливали в прокосах в течение 7 ч до содержания сухого вещества 43,5\%. Динамику рН, содержание аммиака, сахаров и кислот брожения изучали при сенажировании люцерны в лабораторных сосудах обычным способом. Сенаж анализировали через 0, 4, 7, 14, 28, 60 и 90 сут хранения. Состав микробного сообщества исходной растительной массы и сенажа из люцерны анализировали в динамике с использованием молекулярно-биологического метода NGS-секвенирования по модифицированнной методике. Во второй серии опытов изучали влияние препарата молочнокислых бактерий Биотроф (OOO «Биотроф», Россия) на основе Lactobacillus plantarum № 60 на сохранность и биохимические показатели сенажа из люцерны сорта Пастбищная 88, провяленной до содержания сухого вещества 47,6 и 51,3 \%. Сенаж заготавливали в лабораторных емкостях объемом 0,5 л, оснащенных устройствами для учета выделившихся газов, без внесения добавок и с введением препарата Биотроф в рекомендуемой заводомизготовителем дозе $\left(10^{5} \mathrm{KOE} / г\right.$ зеленой массы). Было показано, что при кратковременном провяливании люцерны до сенажной влажности в сухом веществе растений образуется 0,03-0,04\% аммиака и 0,08\% масляной кислоты, содержание которых в начале сенажирования возрастает соответственно до 0,08-0,09 и 0,13-0,14\%. При провяливании и в начале сенажирования люцерны наблюдалось заметное увеличение содержания моносахаров в ее сухом веществе. Кроме того, при провяливании в сухом веществе люцерны накапливается до 3,7 \% и более яблочной кислоты, которая, как и сахар, способна сбраживаться молочнокислыми бактериями. Продуценты масляной кислоты - бактерии семейства Clostridiaceae в процессе ферментации не обнаруживались. Среди бактерий класса Clostridia в сенаже при хранении были выявлены типичные обитатели рубца - бактерии семейств Eubacteriaceae, Lachnospiraceae, Peptostreptococcaceae и Ruminococcaceae. Мы выявили связь между возрастанием обилия бактерий рода Ruminococcus и увеличением количества яблочной кислоты $(r=0,80$ при $\mathrm{p} \leq 0,05)$, а также между возрастанием количества яблочной кислоты и увеличением численности бактерий филума Bacteroides, присутствующих в сенаже $(r=0,84$ при $\mathrm{p} \leq \mathbf{0 , 0 5})$. Накопление яблочной кислоты улучшало сбраживаемость растений, обусловливая быстрое подкисление корма до рН 4,4-4,3 под влиянием внесенного препарата молочнокислых бактерий Биотроф. Этот прием улучшал биохимические показатели корма, способствуя снижению содержания в нем масляной кислоты, однако не приводил к заметному улучшению сохранности питательных веществ и повышению энергетической питательности сухого вещества полученного сенажа вследствие благоприятного процесса брожения в провяленной люцерне. Ускорение подкисления провяленной массы препаратом Биотроф не оказывало существенного влияния и на сокращение образования аммиака в процессе ферментации. До 4-14-х сут хранения в сенаже без добавок выживали микроорганизмы Staphylococcus arlettae, Salmonella subterranea, Streptococcus gordonii, Enterococcus cecorum, способные вызывать заболевания людей и животных. В связи с этим хранящийся сенаж, заложенный с технологическими нарушениями, может содержать патогены сельскохозяйственных животных, что определяет необходимость применения биопрепаратов с антимикробной активностью для его консервирования. Основной эффект от использования биопрепарата при сенажировании люцерны сводился лишь к улучшению биохимических показателей корма, не приводя к заметному повышению его сохранности. 
Ключевые слова: люцерна, сенаж, протеолиз, микробиота, биопрепараты, молочнокислые бактерии, подкисление, качество корма, NGS-секвенирование, количественная ПЦР.

Люцерна принадлежит к несилосующимся растениям, поскольку бедна сахаром и обладает высокой буферной емкостью (1). Значительное влияние на результат консервирования оказывают биологические особенности этого вида. Оптимальный $\mathrm{pH}$, необходимый для функционирования протеаз у люцерны, более низкий, нежели у клевера лугового или злаковых трав (2). Более того, основные протеазы, под влиянием которых большая часть содержащегося в люцерне белка гидролизуется до небелкового азота, проявляют максимальную активность при рН 4,0 (3), чем обусловлен интенсивный протеолиз в силосуемой массе даже в случае быстрого создания в ней необходимой активной кислотности (4). Не способствует получению качественного силоса и наличие в люцерне большого количества белка и пектина. Содержание последнего в сухом веществе листьев и стеблей растений достигает соответственно 10-12 и 6-9 \% (5). Даже в люцерне, провяленной до содержания сухого вещества 30-35 \%, присутствует значительное количество слабосвязанной с белком и пектином воды, что на фоне небольшого подкисления корма способствует развитию в нем бактерий, осуществляющих гнилостное брожение. По этой причине люцерну чаще используют на сенаж, провяливая растения до содержания сухого вещества 45-50 \% (6). Однако в силу указанных выше причин в корме все равно может накапливаться некоторое количество масляной кислоты (7). Чтобы не допустить этого, рекомендуется ускорять подкисление сенажируемой люцерны за счет внесения препаратов молочнокислых бактерий (8).

Поскольку при сенажировании люцерны, наряду с необходимым провяливанием растений, играет роль степень их подкисления, важное значение имеют приемы, направленные на улучшение сбраживаемости провяленной массы. По имеющимся данным, увеличить содержание сахара в сухом веществе люцерны и, следовательно, улучшить ее сбраживаемость можно за счет кратковременного (4-8 ч) провяливания в прокосах до сенажной влажности (9). Однако механизм этого процесса до конца еще не изучен. Не полностью понятны причины увеличения содержания сахара при сенажировании люцерны, хотя само это явление известно достаточно давно. Нет окончательной ясности касательно образования масляной кислоты в люцерновом сенаже. Некоторые авторы утверждают, что в этом случае масляная кислота вообще не накапливается, несмотря на наличие в провяленной массе спор клостридий (10).

Ряд исследователей полагают, что сохранность сенажа связана исключительно с явлением физиологической сухости, которая и сдерживает развитие гнилостной микрофлоры $(11,12)$. В настоящее время в России исследования микрофлоры консервированных кормов с использованием молекулярно-биологических методов проводятся только в лаборатории ООО «БИОТРОФ» (г. Санкт-Петербург). Работы зарубежных авторов посвящены анализу микробиоценоза силоса $(13,14)$. Это может быть связано с проблемой получения чистого материала ДНК микрофлоры сенажа в связи с присутствием в массе большого количества органических примесей (полисахаридов, различных органических кислот, продуктов распада протеина и жиров, нуклеаз и др.) (15), которые могут снижать качество очистки ДНК (16). Ранее нами впервые в России была оптимизирована методика выделения ДНК микробного сообщества для сенажа (17). С использованием молекулярно-биологических методов Т-RFLP (terminal restriction fragment 
length polymorphism) и количественной ПЦР мы изучили состав микрофлоры сенажа из люцерны, подвяленного до содержания сухого вещества $55 \pm 1,9 \%$, на 30 -е сут хранения. Общее количество бактерий в составе микрофлоры сенажа составляло $1,1 \times 10^{8} \pm 3,4 \times 10^{6}$ геномов/г. Число филотипов

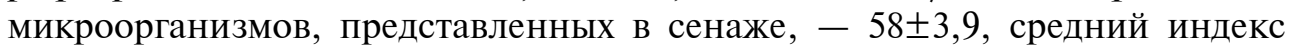
Шеннона $-3,3 \pm 0,22$, Симпсона $-0,96 \pm 0,05$. Эти результаты продемонстрировали сложность организации микробных сообществ сенажа.

По нашему мнению, дальнейшее изучение микробиоэкосистемы сенажа в динамике крайне интересно: такая экосистема постоянно изменяется и подвергается антропогенному вмешательству, что делает ее уникальной и сложной экологической нишей.

В настоящей работе впервые в России выявлено разнообразие состава микроорганизмов при ферментации сенажа с применением NGS-ceквенирования. В процессе ферментации не обнаруживались типичные силосные микроорганизмы - продуценты масляной кислоты семейства Clostridiaceae. Среди бактерий класcа Clostridia в сенаже в процессе хранения были выявлены типичные обитатели рубца - бактерии семейств Eubacteriaceae, Lachnospiraceae, Peptostreptococcaceae и Ruminococcaceae. Впервые выявлена связь между возрастанием обилия бактерий рода Ruminococcus и увеличением количества яблочной кислоты, а также между увеличением количества яблочной кислоты и ростом численности бактерий филума Bacteroides.

Целью работы было изучение особенностей ферментации и структуры микробиома при обычном сенажировании люцерны и при применении препарата молочнокислых бактерий Биотроф.

Методика. Опыты проводили в 2018-2019 годах. В первом опыте исследовали особенности биохимических и микробиологических процессов, возникающих при сенажировании люцерны. В качестве сырья использовали люцерну изменчивую Medicago sativa L. nothosubsp. varia (Martyn) Arcang сорта Пастбищная 88 (экспериментальное поле ФНЦ кормопроизводства и агроэкологии им. В.Р. Вильямса, Московская обл.). Уборку культуры осуществляли в фазу бутонизации. Перед закладкой в стеклянные бутыли объемом 0,5 л люцерну подвяливали в прокосах в течение 7 ч до содержания сухого вещества 43,5 \%. Динамику $\mathrm{pH}$, содержание аммиака, сахара и кислот брожения изучали при сенажировании люцерны в лабораторных сосудах обычным способом. Сенаж анализировали через 0, 4, 7, 14, 28, 60 и 90 сут хранения. Одновременно полученные образцы корма замораживали при $-25{ }^{\circ} \mathrm{C}$ для молекулярно-биологических исследований.

Состав микробного сообщества исходной растительной массы и сенажа из люцерны анализировали в динамике с использованием NGS-секвенирования по модифицированной методике (17). Тотальную ДНК из исследуемых образцов выделяли с помощью набора Genomic DNA Purification Kit («Fermentas, Inc.», Литва) согласно прилагаемой инструкции. При получении продуктов для последующего NGS-секвенирования проводили ПЦР на ДНК-амплификаторе Veriti Thermal Cycler («Life Technologies, Inc.», США) с эубактериальными праймерами (IDT) 343F (5'-CTCCTACGGRRSGCAGCAG-3') и 806R (5'-GGACTACNVGGGTWTCTAAT-3'), фланкирующими участок V1V3 гена 16S рPHK. Метагеномное секвенирование (система MiSeq, «Illumina, Inc.», США) осуществляли с использованием набора MiSeq Reagent Kit v3 («Illumina, Inc.», США). Максимальная длина полученных последовательностей составляла 2×300 п.н. Химерные последовательности исключали из анализа с помощью программы USEARCH 7.0 
(http://drive5.com/usearch/). Обработка полученных ридов $2 \times 300$ п.н. происходила с помощью биоинформатической платформы CLC Bio GW 7.0 («Qiagen N.V.», Нидерланды) и включала выявление перекрывающихся сиквенсов с прямого и обратного праймеров для однозначного прочтения последовательности, фильтрацию по качеству (QV > 15), триммирование праймеров. Таксономическую принадлежность микроорганизмов до рода определяли в программе RDP Classifier (https://sourceforge.net/projects/rdpclassifier/).

Количественную ПЦР (РЦР-PB, qPCR) проводили с использованием детектирующего амплификатора DTlite-4 (OOO «НПО ДНК-Технология», Россия) с помощью набора реактивов для проведения ПЦР-РВ в присутствии интеркалирующего красителя EVA Green (ЗАО «Синтол», Россия) и праймеров HDA1 (5'-ACTCCTACGGGAGGCAGCAG-3') и HDA2 (5'-GTATTACCGCGGCTGCTGGCA-3'). Условия амплификации были следующими: 3 мин при $95{ }^{\circ} \mathrm{C}$ (1 цикл); 1 мин при $95{ }^{\circ} \mathrm{C}, 1$ мин при $57,6{ }^{\circ} \mathrm{C}, 1$ мин при $72{ }^{\circ} \mathrm{C}$ (40 циклов); 5 мин при $72{ }^{\circ} \mathrm{C}$ (1 цикл).

Разнообразие бактериального сообщества оценивали графически в виде тепловой карты, построенной при помощи пакета «pheatmap» Version: 1.0.12 для R (https://cran.r-project.org/web/packages/pheatmap/pheatmap.pdf). Иерархическую кластеризацию по образцам проводили по методу Уорда (Ward's method) на матрице, построенной по евклидовым расстояниям между объектами.

Во второй серии опытов изучали влияние препарата молочнокислых бактерий Биотроф (ООО «Биотроф», Россия) на основе Lactobacillus plantarum № 60 на сохранность и биохимические показатели сенажа из люцерны сорта Пастбищная 88, провяленной до содержания сухого вещества 47,6 и $51,3 \%$. Сенаж заготавливали в лабораторных емкостях объемом 0,5 л, оснащенных устройствами для учета выделившихся газов, без внесения добавок и с введением препарата Биотроф в рекомендуемой заводом-изготовителем дозе $\left(10^{5} \mathrm{KOE} / г\right.$ зеленой массы).

Содержание сухого вещества в зеленой массе и полученном корме определяли посредством высушивания навесок при $105^{\circ} \mathrm{C}$ до постоянной массы, количество сахара - по методу Бертрана, аммиака - по Лонги, $\mathrm{pH}$ - потенциометром И-500 (Россия), органических кислот (молочной, уксусной, масляной, муравьиной, пропионовой, янтарной, яблочной, лимонной, винной, щавелевой) - методом капиллярного электрофореза (KАПЕЛЬ-105М, «Люмэкс», Россия).

Математическую и статистическую обработку результатов осуществляли стандартными методами дисперсионного анализа в программах Microsoft Excel XP/2003, PAST (http://priede.bf.lu.lv/ftp/pub/TIS/datu_analiize/PAST/2.17c/download.html) и R-Studio (https://rstudio.com). Результаты представлены как средние $(M)$ и стандартные ошибки средних ( $\pm \mathrm{SEM})$. Различия оценивали с использованием $t$-критерия Стьюдента. Достоверными считали результаты при $\mathrm{p} \leq 0,05$.

Результаты. Было установлено, что даже в течение 7-часового провяливания люцерны в прокосах в ее сухом веществе накапливалось до $0,03 \%$ аммиака и 0,08 \% масляной кислоты (табл. 1). Основной причиной накопления аммиака был гидролиз белка, происходящий под влиянием растительных ферментов, с последующим дезаминированием образовавшихся аминокислот.

Важно, однако, отметить, что при непродолжительном провяливании 
люцерны до сенажной влажности накопление аммиака в ее сухом веществе не возрастало по сравнению с его содержанием в сухом веществе свежескошенной люцерны. Это указывает на то, что наряду с распадом белка при провяливании люцерны происходят синтетические процессы, при которых аммиак расходуется на образование амидов. Последнее, как известно, происходит при условии сохранения в провяленной массе высокой интенсивности дыхания.

1. Биохимические показатели сенажа из люцерны изменчивой Medicago sativa $\mathrm{L}$. nothosubsp. varia (Martyn) Arcang сорта Пастбищная 88, провяленной до содержания сухого вещества 43,5 \%, по срокам хранения (лабораторный опыт)

\begin{tabular}{|c|c|c|c|c|c|c|c|}
\hline \multirow{2}{*}{ Показатель } & \multicolumn{7}{|c|}{ Срок хранения, сут } \\
\hline & 0 & 4 & 7 & 14 & 28 & 60 & 90 \\
\hline \multicolumn{8}{|c|}{ Содержание в сухом веществе, \%: } \\
\hline caxapa & 4,52 & $5,24^{*}$ & $4,01^{*}$ & $5,55^{*}$ & $4,45^{*}$ & $2,28^{*}$ & $1,25^{*}$ \\
\hline \multicolumn{8}{|l|}{ органических кислот } \\
\hline молочной & 0,09 & $0,76^{*}$ & 1,00 & $0,21 *$ & $0,61^{*}$ & $4,17^{*}$ & $6,09^{*}$ \\
\hline уксусной & 0,05 & $0,35^{*}$ & $0,13^{*}$ & $0,21 *$ & 0,19 & $0,34 *$ & $0,45^{*}$ \\
\hline масляной & 0,08 & $0,13^{*}$ & 0,13 & 0,14 & 0,11 & 0,11 & 0,10 \\
\hline янтарной & 0,09 & $0,15^{*}$ & 0,15 & 0,20 & 0,19 & 0,24 & $0,34^{*}$ \\
\hline яблочной & 3,72 & 3,90 & $3,19^{*}$ & $3,89 *$ & $3,12^{*}$ & $2,05^{*}$ & 2,03 \\
\hline лимонной & 0,48 & 0,48 & 0,50 & 0,48 & 0,45 & 0,34 & $0,19^{*}$ \\
\hline $\mathrm{pH}$ & 6,18 & $5,92^{*}$ & 5,93 & 5,95 & $5,87^{*}$ & $5,32 *$ & $4,93^{*}$ \\
\hline
\end{tabular}

Есть основания полагать, что с возникновением синтетических процессов связано и довольно значительное увеличение содержания сахара в сухом веществе провяливаемой массы люцерны. Это явление все еще объясняют гидролизом крахмала, содержащегося в растениях, под влиянием ферментов. Однако такое утверждение не подтверждается имеющимися экспериментальными данными. В частности, установлено, что при провяливании в растениях накапливается не мальтоза, как это следовало бы ожидать при гидролизе крахмала, а сахароза, служащая основным продуктом фотосинтеза (18). Исходя из общепризнанной точки зрения, авторы объясняют это тем, что при распаде крахмала сахароза образуется не первичным, а вторичным путем, то есть в результате ее последующего синтеза из глюкозы и фруктозы. В то же время имеющиеся данные показывают, что такой процесс протекает только при обезвоживании люцерны на солнце в прокосах и не инициируется при провяливании растений в темноте (9). Это служит доказательством того, что содержание сахара при кратковременном провяливании люцерны увеличивается в результате фотосинтеза, который какое-то время протекает и в скошенной массе.

Первоначальное и не совсем верное толкование обсуждаемого вопроса, очевидно, сложилось на основе полученных данных. В частности, было установлено, что фотосинтез замедляется при утрате растениями влаги свыше 15-20 \%, тогда как дыхание интенсивно протекает и при более высокой степени провяливания растений (19). Отсюда вполне можно было заключить, что замедленный фотосинтез на фоне интенсивного дыхания не может обеспечить заметного увеличения содержания сахара в сухом веществе провяленной массы.

Однако стало известно, что при интенсивном обезвоживании в первую очередь прекращается рост растений, затем угнетается фотосинтез и только потом подавляется дыхание растительных клеток (20). Именно прекращение роста растений, обусловливающее задержку оттока образовавшейся при фотосинтезе сахарозы в другие органы, в том числе в уже отторгнутую от них корневую систему, способствует заметному увеличению 
содержания сахара в вегетативной массе. Это явление носит защитный характер и имеет принципиальное значение при выращивании растений в условиях засухи. Несмотря на прекращение роста вегетативной массы, корневая система (и прежде всего ее ростовые зоны) еще находятся в довольно благоприятных условиях и используют избыток образовавшегося в листьях сахара на собственный усиленный рост, приводящий к освоению более глубоких и, следовательно, и более обводненных слоев почвы.

Как отмечено выше, при интенсивном провяливании на сенаж люцерна еще сохраняет высокую интенсивность дыхания за счет адаптивной перестройки дыхательного аппарата для работы в условиях обезвоживания. На это, в частности, указывает высокое накопление в сухом веществе провяленной массы яблочной кислоты, что позволяет растениям синтезировать лимонную кислоту непосредственно из яблочной (21). Описанный механизм позволяет снизить зависимость растений от такого затратного процесса, как гликолиз, одновременно обеспечивая работу цикла Кребса по укороченному типу. Между тем провяленная до указанного содержания сухого вещества люцерна уже страдает от недостатка кислорода. На это, в частности, указывает накопление в ней некоторого количества янтарной кислоты. Появление последней свидетельствует о выходе ее из митохондрий и служит показателем развития в массе прогрессирующей гипоксии (22). При нормальном дыхании растений янтарная кислота либо не обнаруживается, либо определяется в следовых количествах, поскольку образуется только в митохондриях, где моментально утилизируется. С наступлением гипоксии, очевидно, связано и накопление в провяленной массе люцерны некоторого количества масляной кислоты. В литературе имеются сообщения (18), указывающие на возможность синтеза масляной кислоты в растениях при недостатке кислорода из-за нарушения жирового обмена. Яблочная кислота, или малат, образуется в результате гликолитического распада крахмала, который на свету очень быстро синтезируется из сахарозы, образующейся при фотосинтезе, и откладывается в хлоропластах (23). Этим и объясняется тот факт, что при провяливании люцерны в темноте, то есть в отсутствие фотосинтеза, в ней уже не образуются ни сахара, ни яблочная кислота (9).

Увеличение содержания сахаров, а следовательно, и улучшение сбраживаемости люцерны наблюдалось и в первые 4 сут ее сенажирования. Как и при провяливании, это явление было направлено на сохранение жизнедеятельности растений в условиях наступающего анаэробиоза, но осуществлялось за счет использования собственных запасных питательных веществ. В соответствии с имеющимися данными (24), основным источником сахара в этом случае служит гидролиз гемицеллюлоз, возникающий под влиянием растительных ферментов.

Из полученных нами результатов следует, что наиболее ярко этот процесс протекал в самом начале сенажирования люцерны, когда в ней еще не происходило заметного брожения, связанного с накоплением органических кислот. По мере увеличения интенсивности молочнокислого брожения на заключительных этапах сенажирования содержание сахара заметно снижалось.

Наряду с увеличением содержания моносахаров важное условие улучшения сбраживаемости люцерны - возможность использования молочнокислыми бактериями яблочной кислоты, накопление которой в сухом веществе провяленной массы лишь ненамного уступало содержанию сахара. Наши исследования показали, что, как и в случае с моносахарами, сбраживание яблочной кислоты происходило лишь на поздних этапах сенажирования, 
когда в корме заметно возрастало содержание молочной кислоты. Из этого можно заключить, что главным условием сбраживания и яблочной кислоты, и моносахаров становилось обеспечение развития в корме интенсивного молочнокислого брожения. То же самое можно отметить и по отношению к содержащейся в растениях лимонной кислоте.

Согласно полученным нами данным, достоверное $(\mathrm{p} \leq 0,05)$ увеличение содержания аммиака в сухом веществе сенажируемой массы отмечалось лишь в первые 2 нед. Затем его количество стабилизировалось и не менялось в течение всего последующего срока хранения корма. В деградации белка при сенажировании и силосовании провяленной массы люцерны исследователи обычно выделяют два основных этапа (25). На первом этапе ферментации массы активность в основном проявляют растительные энзимы, обусловливая распад белка до свободных аминокислот. Основную роль в дезаминировании аминокислот, то есть в накоплении аммиака как такового отводят микробным ферментам.

Некоторые авторы отмечают, что определенное количество аммиака может образовываться и в результате воздействия на белок растительных ферментов (18). К такому выводу они пришли на основании результатов опытов по силосованию клевера лугового с толуолом. Последний, как известно, подавляет развитие бактерий, не оказывая заметного отрицательного влияния на активность энзимов. Установлено, что и при отсутствии развития бактерий в корме распад белка сопровождался накоплением в массе некоторого количества аммиака, азот которого составлял до 5,0 \% от общего азота корма. Не исключено, однако, что в этом случае добавка толуола, обусловливая гибель и лизис бактериальных клеток, способствовала выходу содержащихся в них ферментов во внешнюю среду. Иными словами, в протеолизе участвовали и растительные, и микробные ферменты.

В первые 4 сут сенажирования мы также отмечали достоверное $(\mathrm{p} \leq 0,05)$ увеличение содержания масляной кислоты в сухом веществе корма, которое возросло в 1,6 раза по сравнению с накоплением в сухом веществе исходной провяленной люцерны. Тот факт, что масляная кислота образовывалась в самом начале сенажирования люцерны, когда в ней еще не отмечалось сколько-нибудь заметного брожения, указывает на то, что, как и при провяливании, некоторое количество масляной кислоты может образовываться чисто биохимическим путем, то есть без участия микробов.

Так, В.А. Маевский с соавт. (26), опираясь на результаты, полученные в опытах на животных, отмечают, что в условиях гипоксии в митохондриях заметно возрастает количество НАДН, что приводит к снижению окисления НАД-зависимых субстратов. В результате наблюдается избыточное накопление ацетил-КоА - продукта $\beta$-окисления жиров, дальнейшее окисление которого сдерживается из-за того, что прирост НАДН вызывает быстрое восстановление оксалоацетата до малата. В итоге ацетил-КоА остается без партнера, необходимого для вступления в цикл Кребса, и вместо полного окисления становится источником образования кетоновых тел, жирных кислот и холестерина. Зарубежные исследователи полагают, что, при заготовке силоса из провяленной люцерны в ней, наряду с протеолизом, активно протекает процесс липолиза, основной причиной возникновения которого служит растительная, а не микробная липаза (27).

Для более детального изучения природы аммиака и масляной кислоты, образующихся при сенажировании люцерны, мы определили динамику общей численности и видовой состав микроорганизмов по срокам хранения корма. 
2. Состав микроорганизмов в сенаже люцерны изменчивой Medicago sativa L. nothosubsp. varia (Martyn) Arcang copта Пастбищная 88 (содержание сухого вещества 43,5 \%) при хранении от 4 до 90 сут ( $M \pm \mathrm{SEM}, n=3$, лабораторный опыт)

\begin{tabular}{|c|c|c|c|c|c|c|c|}
\hline \multirow{2}{*}{ Таксон } & \multirow{2}{*}{$\begin{array}{l}\text { Исходная } \\
\text { растительная масса }\end{array}$} & \multicolumn{6}{|c|}{ Срок хранения сенажа, сут } \\
\hline & & 4 & 7 & 14 & 28 & 60 & 90 \\
\hline \multicolumn{8}{|c|}{ К ол и ч е с т в е н н а я П Ц Р, клеток/Г } \\
\hline Общее число бактерий & $3,3 \times 10^{8} \pm 1,4 \times 10^{7}$ & $2,0 \times 10^{7} \pm 1,1 \times 10^{6 *}$ & $9,0 \times 10^{6} \pm 2,1 \times 10^{5 *}$ & $4,2 \times 10^{6} \pm 5,6 \times 10^{5}$ & $1,15 \times 10^{7} \pm 9,9 \times 10^{5 *}$ & $1,5 \times 10^{6} \pm 9,3 \times 10^{5 *}$ & $1,15 \times 10^{7} \pm 8,9 \times 10^{5 *}$ \\
\hline \multicolumn{8}{|c|}{ NGS-cекве н и ров ан ие, \% } \\
\hline Не классифицируемые бактерии & $14,80 \pm 0,790$ & $47,08 \pm 2,600^{*}$ & $50,00 \pm 3,100$ & $53,85 \pm 3,500$ & $35,96 \pm 1,900^{*}$ & $45,45 \pm 2,300^{*}$ & $50,91 \pm 3,900$ \\
\hline Класс Acidobacteria & $62,56 \pm 3,400$ & $3,64 \pm 0,210^{*}$ & $1,43 \pm 0,073^{*}$ & 0 & $1,12 \pm 0,059^{*}$ & 0 & 0 \\
\hline Класс Actinobacteria & $1,29 \pm 0,070$ & $0,73 \pm 0,050^{*}$ & $4,29 \pm 0,340^{*}$ & $1,10 \pm 0,054^{*}$ & 0 & 0 & 0 \\
\hline Класс Aiphaproteobacteria & $2,76 \pm 0,150$ & $0,73 \pm 0,048^{*}$ & $1,43 \pm 0,062$ & 0 & $23,60 \pm 1,700^{*}$ & 0 & 0 \\
\hline Класс Anaerolineae & $0,02 \pm 0,001$ & 0 & 0 & 0 & 0 & 0 & 0 \\
\hline Класс Aquificae & $0,02 \pm 0,002$ & 0 & 0 & 0 & 0 & 0 & 0 \\
\hline Класс Armatimonadia & $0,02 \pm 0,002$ & 0 & 0 & 0 & 0 & 0 & 0 \\
\hline Класс Bacilli: & $1,76 \pm 0,080$ & $14,05 \pm 0,720^{*}$ & $7,14 \pm 0,360^{*}$ & $1,10 \pm 0,052^{*}$ & $7,87 \pm 0,420^{*}$ & $31,82 \pm 1,750^{*}$ & $45,45 \pm 2,600^{*}$ \\
\hline сем. Bacillaceae & $0,37 \pm 0,020$ & $2,74 \pm 0,150^{*}$ & $4,29 \pm 0,29 *$ & $1,10 \pm 0,049^{*}$ & $1,12 \pm 0,059$ & $4,55 \pm 0,310^{*}$ & 0 \\
\hline сем. Staphylococcaceae & 0 & 0 & $1,43 \pm 0,081^{*}$ & 0 & 0 & 0 & 0 \\
\hline сем. Lactobacillaceae & $1,39 \pm 0,078$ & $11,31 \pm 0,450^{*}$ & $4,29 \pm 0,330^{*}$ & 0 & $6,74 \pm 0,450^{*}$ & $27,27 \pm 1,600^{*}$ & $45,45 \pm 2,400^{*}$ \\
\hline Класс Bacteroidia & $1,16 \pm 0,063$ & $3,47 \pm 0,190^{*}$ & $12,86 \pm 0,520$ & $17,58 \pm 0,92^{*}$ & 0 & $4,55 \pm 0,380^{*}$ & $1,82 \pm 0,160^{*}$ \\
\hline Класс Betaproteodacteria & $1,45 \pm 0,081$ & $0,18 \pm 0,009^{*}$ & 0 & 0 & 0 & 0 & 0 \\
\hline Класс Caldilineae & $0,02 \pm 0,002$ & 0 & 0 & 0 & 0 & 0 & 0 \\
\hline Класс Caldisericia & $0,06 \pm 0,003$ & 0 & 0 & 0 & 0 & 0 & 0 \\
\hline Класс Chthonomonadetes & $0,35 \pm 0,020$ & 0 & 0 & 0 & 0 & 0 & 0 \\
\hline Класс Clostridia & $1,23 \pm 0,073$ & $3,10 \pm 0,220^{*}$ & $15,71 \pm 0,800^{*}$ & $19,78 \pm 0,99^{*}$ & 0 & $9,09 \pm 0,560^{*}$ & 0 \\
\hline Класс Cytophagia & $0,31 \pm 0,030$ & $0,18 \pm 0,007^{*}$ & 0 & 0 & 0 & 0 & 0 \\
\hline Класс Deinococci & $0,02 \pm 0,004$ & 0 & 0 & 0 & 0 & 0 & 0 \\
\hline Класс Deltaproteobacteria & $0,06 \pm 0,004$ & 0 & 0 & 0 & 0 & $4,55 \pm 0,290^{*}$ & 0 \\
\hline Класс Erysipelotrichia & $0,02 \pm 0,002$ & 0 & 0 & 0 & 0 & 0 & 0 \\
\hline Класс Flavobacteria & $0,15 \pm 0,008$ & $0,18 \pm 0,008$ & 0 & 0 & 0 & 0 & 0 \\
\hline
\end{tabular}


Kласс Gammaproteobacteria:

rop. Enterobacteriales:

Salmonella subterranea

Класс Mollicutes

Пор. Selenomonadales (класс Negativicutes)

Класс Opitutae

Класс Phycisphaerae

Класс Planctomycetia

Класс Sphingobacteriia

Класс Spirochaetia

Класс Synergistia

Класс Thermodesulfobacteria

Класс Thermomicrobia

Класс Verrucomicrobiae
$11,03 \pm 0,750$

$5,61 \pm 0,290$$$
0
$$

$0,04 \pm 0,005$

$0,10 \pm 0,005$

$0,02 \pm 0,003$

$0,02 \pm 0,001$

$0,04 \pm 0,004$

$0,50 \pm 0,150$

$0,04 \pm 0,006$

$0,020 \pm 0,0021$

$0,020 \pm 0,0026$

$0,020 \pm 0,0015$

$0,020 \pm 0,0023$
$26,09 \pm 1,500^{*}$

$23,54 \pm 1,200^{*}$

$0,36 \pm 0,019 *$

0

$0,55 \pm 0,030^{*}$

0
0
0
0
0
0
0
0
0

* Разница с показателем в предыдущий срок статистически значима при $\mathrm{p} \leq 0,05$.
$2,20 \pm 0,190^{*}$

$, 10 \pm 0,150^{*}$

$3,30 \pm 0,220^{*}$

0

0

$1,10 \pm 0,130^{*}$

0
$31,46 \pm 1,460^{*}$

$30,34 \pm 1,110^{*}$

0
0
0
0
0
0
0
0
0
0
0
0

Продолжение таблицы 2

$4,55 \pm 0,300^{*} \quad 1,82 \pm 0,170^{*}$

0
0
0
0
0
0
0

0 
Анализ, проведенный с использованием метода количественной ПЦР, показал, что общая численность бактерий в сенаже во все сроки составляла от $1,5 \times 10^{6} \pm 9,3 \times 10^{5}$ до $2,0 \times 10^{7} \pm 1,1 \times 10^{6}$ клеток/г (табл. 2). То есть люцерновый сенаж на всех этапах хранения был довольно значительно контаминирован микроорганизмами, что указывает на достаточно активную микробиологическую ферментацию и вступает в противоречие с данными об отсутствии в сенаже процессов микробного брожения $(11,12)$. Тем не менее, сопоставляя полученные данные с нашими предыдущими результатами по силосу (17), следует отметить, что процессы ферментации в сенаже менее активны. Мы показали, что общее содержание бактерий в силосной экосистеме при консервировании многолетних трав составляло от $5,2 \times 10^{7}$ до $9,4 \times 10^{9}$ геномов/г.

При этом состав микрофлоры сенажа резко отличался от состава эпифитных микроорганизмов исходной растительной массы люцерны и менялся в процессе сукцессионных изменений, происходящих во время хранения (см. табл. 2). Вероятно, эти изменения происходили в результате создания анаэробных условий и изменения биохимического состава корма. Так, состав микрофлоры сенажа был представлен 8 филумами микроорганизмов (рис.), тогда как структура эпифитной микрофлоры включала 18 филумов бактерий.

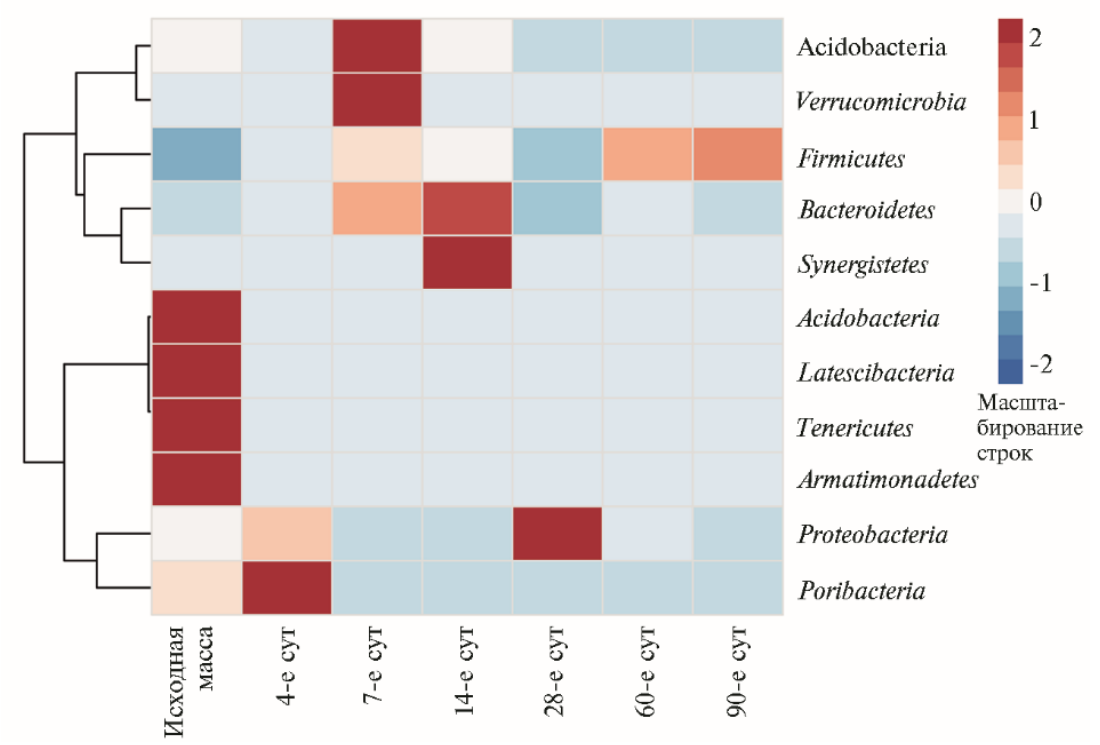

Тепловая карта бактериального сообщества исходной растительной массы люцерны изменчивой Medicago sativa L. nothosubsp. varia (Martyn) Arcang сорта Пастбищная 88 и сенажа в процессе хранения (лабораторный опыт). Минорные филумы (доля меньше 0,06 \%) Fusobacteria, Spirochaetes, Chloroflexi, Aquificae, Planctomycetes, Caldiserica и Thermodesulfobacteria на рисунке не представлены.

На скошенной растительной массе люцерны достоверно доминировали $(62,6 \pm 3,4 \%$ при р $\leq 0,05)$ типичные (28) микроорганизмы филума Acidobacteria (см. рис.). Несмотря на их широкую представленность в окружающей среде, познание метаболизма этих бактерий находится в зачаточном состоянии в связи с практически полной невозможностью культивирования на питательных средах. Сведения об присутствии этих бактерий в составе эпифитной микрофлоры растений были получены только после появления методик анализа последовательностей генов 16S рPНК (29).

Содержание бактерий филума Acidobacteria резко уменьшалось (до 
$3,64 \pm 0,21$ при $\mathrm{p} \leq 0,05)$ уже на 4-е сут хранения сенажа, а после 28 сут эти бактерии практически полностью элиминировались. Полученные данные закономерны, поскольку бактерии филума Acidobacteria олиготрофны (30), и, вероятно, богатая питательными веществами экосистема хранящегося корма для них неблагоприятна. В то же время доминирующими бактериями на протяжении хранения сенажа были представители филумов Firmicutes, Bacteroidetes и Proteobacteria, что повторяет тенденции, наблюдаемые при развитии силосной сукцессии $(13,31)$.

Тем не менее даже через 3 мес хранения лишь около половины содержащихся в корме микроорганизмов были представлены молочнокислыми бактериями семейства Lactobacillaceae (см. табл. 2) филума Firmicutes - традиционными обитателями микрофлоры силоса (31). Вероятно, условия среды, характерные для сенажа (pH, содержание сухого вещества и т.д.), оказались не так благоприятны для жизнедеятельности этих микроорганизмов. Известно, что лактобактерии играют определяющую роль в процессах микробного брожения консервированных кормов. Они трансформируют моно- и дисахариды кормов с образованием лактата, что приводит к подкислению корма и вытеснению микрофлоры, осуществляющей нежелательные для сенажа процессы брожение (32).

В качестве особенностей ферментации люцернового сенажа следует отметить отсутствие взаимосвязи между накоплением масляной кислоты и численностью клостридий (класcа Clostridia) в провяленной массе ( $\mathrm{p} \leq 0,05)$. Так, если максимальное количество масляной кислоты в сухом веществе корма образовывалось уже через 4 сут ферментации, то наибольшая численность клостридий отмечалась лишь спустя 14 сут хранения. Это указывает на то, что значительная часть масляной кислоты, появляющейся в самом начале сенажирования люцерны, имеет биохимическое происхождение.

И.И. Филатов с соавт. (33) также не выявили связи между накоплением масляной кислоты с численностью клостридий. Высокую численность маслянокислых бактерий (около $2,0 \times 10^{5} \mathrm{KOE}$ ) в 1 г сенажа из провяленной (47,5 \% сухого вещества) люцерны авторы отмечали в течение всего 90-суточного срока хранения корма. Тем не менее в полученном корме не накапливалась масляная кислота. Это указывает на то, что в сенаже из люцерны споры клостридий в большинстве случаев остаются в неактивном состоянии в течение всего срока хранения корма. В настоящее время такого мнения придерживаются и зарубежные исследователи (10). Однако подобное наблюдается не всегда. Различия в образовании масляной кислоты авторы связывают с сортовыми особенностями люцерны, степенью провяливания растений, от которой, по их мнению, во многом зависит клостридиальное сообщество, а следовательно, время возникновения и интенсивность маслянокислого брожения, и с другими факторами.

Действительно, некоторые представители класса Clostridia, относящиеся к семейству Clostridiaceae, образуют в процессе ферментации, в том числе в консервированных кормах, масляную кислоту. Часть из них ( C. sporogenes, C. bifermentans, C. sphenoides) обладают протеолитическими свойствами, в связи с чем их присутствие в консервированных кормах нежелательно (32). Однако в нашем эксперименте представителей семейства Clostridiaceae выявляли лишь в исходном растительном сырье люцерны, в процессе ферментации их полностью вытесняли представители другой микрофлоры. Интересно, что среди бактерий класса Clostridia в сенаже в процессе хранения обнаруживались такие семейства, как Eubacteriaceae, Lachno- 
spiraceae, Peptostreptococcaceae и Ruminococcaceae. Основные продукты их метаболизма - уксусная, валериановая, яблочная, пропионовая кислоты, при этом масляная кислота образуется в минорных количествах, а некоторые виды бактерий ее не образуют вовсе (34). Интересно, что в нашем эксперименте при расчете корреляций Пирсона была выявлена достоверная связь между возрастанием содержания бактерий рода Ruminococcus и увеличением количества яблочной кислоты $(r=0,8$ при р $\leq 0,05)$. Бактерии семейств Eubacteriaceae, Lachnospiraceae, Peptostreptococcaceae и Ruminococcaceae - это представители нормофлоры кишечного и рубцового микробиоценоза (35).

Очень интересен и заслуживает обсуждения тот факт, что была также обнаружена достоверная связь между увеличением численности бактерий филума Bacteroides и возрастанием содержания моносахаров $(r=0,76$ при $\mathrm{p} \leq 0,05)$, масляной $(r=0,95$ при $\mathrm{p} \leq 0,05)$ и яблочной $(r=0,4$ при $\mathrm{p} \leq 0,05)$ кислот. Это вполне закономерно, поскольку известно, что метаболизм крахмала с высвобождением молекулы глюкозы (36) служит основным путем метаболизма у указанных микроорганизмов. В результате может повышаться биодоступность глюкозы для микроорганизмов, которые продуцируют масляную и яблочную кислоты.

Следовательно, особенность люцернового сенажа состоит в том, что протеолитические формы клостридий не получают в нем существенного развития, то есть корм характеризуется благоприятным направлением процесса брожения.

Тем не менее на 4-е и 28-е сут хранения в сенаже резко возрастало количество бактерий семейства Enterobacteriaceae - соответственно до $23,5 \pm 1,2$ и $30,3 \pm 1,11 \%$ ( $\leq \leq 0,05)$. Они нежелательны для процесса ферментации кормов, потому что источником их жизнедеятельности становятся моносахара, что делает их прямыми конкурентами лактобактерий (32). Среди родов энтеробактерий при хранении сенажа были выявлены как типичные эпифитные бактерии (Erwinia, Serratia, Pantoea), так и патогенные формы (Enterobacter, Escherichia, Shigella, Klebsiella, Salmonella).

Интересно, что до 4-14-х сут хранения в сенаже выживали микроорганизмы Staphylococcus arlettae, Salmonella subterranea, Streptococcus gordonii, Enterococcus cecorum, способные вызывать заболевания людей и животных. Так, коагулазонегативные стафилококки становятся частой причиной бактериемии (37). Они выявляются в крови у людей, больных сердечно-сосудистыми заболеваниями. Ранее Staphylococcus arlettae был выделен с кожных покровов и навоза домашней птицы и коз (37). Salmonella subterranea - это относительно новый вид, обнаруженный в 2004 году в природных источниках (38). Выживание Salmonella subterranea в сенаже на начальных этапах ферментации объяснимо (38). Streptococcus gordonii - это бактерия, которая признана возбудителем бактериального эндокардита и эмпиемы человека (39). У крупного рогатого скота бактерии из рода Streptococcus рассматриваются как патогены, ассоциированные с субклиническим маститом, многими заболеваниями репродуктивной системы (аборт, мертворождение, вульвит, вагинит и метрит), клапанным эндокардитом и септицемией (40). Enterococcus cecorum - возбудитель заболеваний суставов, однако на сегодняшний день его патогенность доказана только для птиц (41). Следовательно, хранящийся сенаж, закладка которого проходила с нарушением технологических приемов, может содержать патогены сельскохозяйственных животных, что определяет необходимость применения биопрепаратов с антимикробной активностью для его консервирования. 
Количество неидентифицированных бактерий в наших опытах составляло от $35,9 \pm 1,9$ до 50,9 $\pm 3,9 \%$. Эти бактерии принадлежали к рангу объектов, для культивирования которых на сегодняшний день не существует питательных сред, поэтому о них стало известно лишь с развитием молекулярно-биологических методов (42). Высокая доля неклассифицируемых микроорганизмов, отмечаемая в сенаже на протяжении всего срока хранения, также не приводила к сколько-нибудь значительному увеличению потерь питательных веществ и ухудшению биохимических показателей полученного корма. Несмотря на присутствие этих микроорганизмов, мы не наблюдали увеличения накопления аммиака и масляной кислоты, а также снижения содержания сахара, сокращение количества которого начиналось только через 2 мес хранения сенажа, то есть после активации в нем молочнокислого брожения. Можно сделать вывод, что интродукция молочнокислых бактерий при сенажировании люцерны не должна сопровождаться каким-либо значительным эффектом.

Чтобы убедиться в этом, мы приготовили сенаж из провяленной люцерны без консерванта и с интродукцией молочнокислых бактерий в виде закваски Биотроф. Внесение препарата Биотроф, стимулируя молочнокислое брожение, обусловило увеличение распада питательных веществ до газообразных продуктов, в результате чего объем выделившихся при сенажировании газов повысился в $1,5-2,4$ раза $(\mathrm{p} \leq 0,05)$ (табл. 3). Это было связано с увеличением сбраживания моносахаров, содержание которых в сухом веществе корма сократилось в $3,1-3,7$ раза ( $\mathrm{p} \leq 0,05)$. Стимуляция молочнокислого брожения обусловливала быстрое подкисление корма до предела, исключающего развитие маслянокислых бактерий. В результате накопление масляной кислоты сократилось в 1,3-2,8 раза по сравнению с ее содержанием в обычном сенаже. Однако и в этом случае накопление масляной кислоты в сухом веществе корма составляло 0,11-0,15\%, то есть ее было столько, сколько может образоваться в результате биохимических процессов.

3. Объем выделившихся газов и биохимические показатели обычного и приготовленного с препаратом Биотроф сенажа из люцерны изменчивой Medicago sativa L. nothosubsp. varia (Martyn) Arcang сорта Пастбищная 88 ( $M \pm \mathrm{SEM}$, $n=3$, лабораторный опыт)

\begin{tabular}{|c|c|c|c|c|c|c|}
\hline \multirow{3}{*}{ Вариант } & \multirow{3}{*}{$\begin{array}{l}\text { Объем выделившихся } \\
\text { газов, л/кг СВ зеле- } \\
\text { ной массы }\end{array}$} & \multirow{3}{*}{$\mathrm{pH}$} & \multicolumn{4}{|c|}{ Содержание в сухом веществе корма, \% } \\
\hline & & & \multirow{2}{*}{ аммиака } & \multicolumn{2}{|c|}{ органических кислот } & \multirow{2}{*}{ моносахаров } \\
\hline & & & & молочной & масляной & \\
\hline \multicolumn{7}{|c|}{ Соде ржание С В в люце рн е $47,6 \%$} \\
\hline Без добавок & $2,39 \pm 0,430$ & $5,59 \pm 0,010$ & $0,23 \pm 0,010$ & $0,30 \pm 0,040$ & $0,20 \pm 0,010$ & $2,26 \pm 0,090$ \\
\hline Биотроф & $5,73 \pm 0,120^{*}$ & $4,31 \pm 0,010^{*}$ & $0,27 \pm 0,010$ & $15,48 \pm 0,320^{*}$ & $0,15 \pm 0,010^{*}$ & $0,73 \pm 0,040^{*}$ \\
\hline \multicolumn{7}{|c|}{ Содержание С В в люце рн е $51,3 \%$} \\
\hline Без добавок & $3,04 \pm 0,220$ & $5,45 \pm 0,090$ & $0,17 \pm 0,010$ & $2,86 \pm 0,100$ & $0,31 \pm 0,040$ & $4,63 \pm 0,260$ \\
\hline Биотроф & $4,62 \pm 0,120^{*}$ & $4,25 \pm 0,010^{*}$ & $0,14 \pm 0,020$ & $14,06 \pm 0,200^{*}$ & $0,11 \pm 0,030^{*}$ & $1,25 \pm 0,040^{*}$ \\
\hline
\end{tabular}

В то же время ускорение подкисления сенажируемой массы люцерны под влиянием препарата Биотроф не приводило к достоверному сокращению накопления в корме аммиака. То есть основным параметром, определяющим степень распада белка до аммиака при силосовании и сенажировании люцерны, служит степень провяливания растений. Согласно имеющимся данным (33), при увеличении содержания сухого вещества в силосуемой массе люцерны с 21,1 до 31,5; 41,5 и 52,0 \% количество аммиачного азота по отношению к общему азоту корма сокращается с 18,6 до 8,8; 4,5 и 4,9 \%. Поскольку использование препаратов молочнокислых бак- 
терий не приводит к заметному улучшению сохранности питательных веществ люцернового сенажа, улучшая лишь его биохимические показатели, оно не обусловливает и заметного увеличения энергетической питательности сухого вещества полученного корма (43). В то же время сенаж из люцерны, обработанной препаратами молочнокислых бактерий, обладает более высоким продуктивным действием (44). Авторы объясняют это явление увеличением общей массы микрофлоры химуса рубца, которая может быть для животных источником протеина.

Таким образом, при кратковременном провяливании люцерны до сенажной влажности и в самом начале ее сенажирования происходило заметное увеличение содержания сахаров в сухом веществе зеленой массы. Кроме того, в провяливаемых растениях в большом количестве накапливалась яблочная кислота, которая, как и моносахара, сбраживалась молочнокислыми бактериями. С применением метода высокопроизводительного секвенирования среди бактерий класса Clostridia в сенаже в процессе хранения были выявлены типичные обитатели рубца из семейств Eubacteriaceae, Lachnospiraceae, Peptostreptococcaceae и Ruminococcaceae. Интересно, что продуценты масляной кислоты - бактерии семейства Clostridiaceae в процессе ферментации не обнаруживались. Показана достоверная связь между возрастанием содержания бактерий рода Ruminococcus и увеличением количества яблочной кислоты, а также между возрастанием содержания яблочной кислоты и увеличением численности бактерий филума Bacteroides. Накопление яблочной кислоты приводило к улучшению сбраживаемости сенажируемой люцерны, в результате чего она под влиянием препарата молочнокислых бактерий Биотроф быстро подкислялась до рН 4,4-4,3, что обеспечивает стабильность корма при хранении. Целесообразность этого приема обусловлена тем, что в сенажируемой массе в большом количестве (до половины от общего количества микроорганизмов) присутствуют неклассифицируемые бактерии, которые не растут на обычных питательных средах и не изучены в достаточной степени. Эти бактерии не приводят к значительным потерям питательных веществ при сенажировании, однако ухудшают биохимические показатели корма, способствуя увеличению накопления в нем масляной кислоты. Поэтому основной эффект от использования препаратов молочнокислых бактерий при сенажировании люцерны сводится лишь к улучшению биохимических показателей корма, не приводя к заметному улучшению его сохранности. В то же время в сенаже обнаруживались микроорганизмы Staphylococcus arlettae, Salmonella subterranea, Streptococcus gordonii, Enterococcus cecorum, которые способны вызывать заболевания людей и животных.

\footnotetext{
1ФГБНУ ФНЦ кормопроизводства и агроэкологии им. В.Р. Вильямса

141055 Россия, Московская обл., г. Лобня, Научный городок, корп. 1, e-mail: yurypobednow@yandex.ru, Anton.mamaev@inbox.ru,

m-latysheva@list.ru;

2000 «ИОТРОФ+»,

192284 Россия, г. Санкт-Петербург, Загребский б-р, 19, корп. 1,

e-mail: deniz@biotrof.ru $₫$, laptev@biotrof.ru, ilina@biotrof.ru, bea@biotrof.ru,

tarlav1995@biotrof.ru
}

Sel’skokhozyaistvennaya biologiya [Agricultural Biology], 2020, V. 55, № 6, pp. 1268-1284

\section{FERMENTATION PROCESSES IN ALFALFA HAYLAGE WITHOUT ADDITIVES AND WITH INTRODUCTION OF Lactobacillus plantarum STRAIN}

Yu.A. Pobednov', A.A. Mamaev ${ }^{1}$, M.S. Shirokoryad ${ }^{1}$, E.A. Yildirim ${ }^{2}{ }^{凶}$, G.Yu. Laptev $^{2}$, 


\section{L.A. Ilyina' ${ }^{2}$,E.A. Brazhnik', N.V. Tarlavin ${ }^{2}$}

${ }^{1}$ Williams Federal Research Center for Fodder Production and Agroecology, 1, Nauchnii Gorodok, Lobnya, Moscow Province, 141055 Russia, e-mail yurypobednow@yandex.ru, Anton.mamaev@inbox.ru,m-latysheva@list.ru;

2JSC «Biotrof+», 19 korp. 1, Zagrebskii bulv., St. Petersburg, 192284 Russia, e-mail deniz@biotrof.ru (corresponding author $₫)$, laptev@biotrof.ru, ilina@biotrof.ru, bea@biotrof.ru, tarlav1995@biotrof.ru

ORCID:

Pobednov Yu.A. orcid.org/0000-0001-8701-009X

Mamaev A.A. orcid.org/0000-0002-7962-4048

Shirokoryad M.S. orcid.org/0000-0001-8333-752X

Yildirim E.A. orcid.org/0000-0002-5846-4844

The authors declare no conflict of interests

Received July 3, 2020

Laptev G.Yu. orcid.org/0000-0002-8795-6659

Ilyina L.A. orcid.org/0000-0003-2490-6942

Brazhnik E.A. orcid.org/0000-0003-2178-9330

Tarlavin N.V. orcid.org/0000-0002-6474-9171

doi: 10.15389/agrobiology.2020.6.1268eng

\section{Abstract}

The optimal $\mathrm{pH}$ required for the functioning of proteases in alfalfa is lower than that of meadow clover or cereal grasses, and this culture is rich in protein and pectin which is not favorable for high-quality feed production. It is recommended to accelerate the acidification of the alfalfa being hayed by adding preparations of lactic acid bacteria. In the present work, for the first time in Russia, a diversity profile of haylage microbiota during fermentation was revealed using NGS sequencing. The work aimed to study the peculiarities of alfalfa fermentation during haylage with and without using Biotrof, a lactic acid bacteria-based preparation. The experiments were performed in 2018-2019. In the first experiment, the peculiarities of biochemical and microbiological processes during alfalfa haylaging were examined. Alfalfa Medicago sativa L. nothosubsp. varia (Martyn) Arcang cv. Pastbishnaya 88 was grown (experimental field, the Williams Federal Research Center for Forage Production and Agroecology, Moscow Province), cut for hay, dried in swaths for 7 hours to a dry matter content of $43.5 \%$ and put into 0.51 glass vessels for haylaging. The $\mathrm{pH}$ dynamics, ammonia, sugar and fermentation acid levels were measured on days $0,4,7,14,28,60$, and 90 of storage. The composition of the microbial community of the plant biomass and the alfalfa haylage was analyzed in dynamics using NGS sequencing according to a modified technique. In the second series of experiments, the effect of the preparation of lactic acid bacteria Biotrof (OOO Biotrof, Russia) based on Lactobacillus plantarum No. 60 on storability and biochemical parameters of the haylage from alfalfa cv. Pastbishnaya 88 biomass dried to a dry matter content of 47.6 and $51.3 \%$, was studied. The biomass was put into 0.51 -containers equipped with devices for measuring evolved gases for two treatment, with no additives and upon introduction of the Biotrof preparation in the recommended dose $\left(10^{5} \mathrm{CFU} / \mathrm{g}\right.$ green mass). It was shown that a short-term wilting of alfalfa biomass to the haylage moisture resulted in 0.03-0.04\% ammonia and $0.08 \%$ butyric acid concertation followed by an increase to 0.08-0.09 and 0.13-0.14\%, respectively, when haylaging. During wilting and early fermentation, the sugar contents in the biomass increased noticeably. In addition, the wilted alfalfa accumulates at least $3.7 \%$ of malic acid which, like sugar, can be fermented by lactic acid bacteria. Butyric acid producers, the bacteria of the Clostridiaceae family, were not detected during fermentation. During haylage storage, among the bacteria of the Clostridia class the typical rumen microorganisms were identified of the families Eubacteriaceae, Lachnospiraceae, Peptostreptococcaceae, and Ruminococcaceae. We have found a relationship between an increase in the abundance of bacteria of the genus Ruminococcus and an increase in the amount of malic acid $(r=0.80, \mathrm{p} \leq 0.05)$, and also between an increase in the amount of malic acid and an increase in the number of bacteria of the phylum Bacteroides in the haylage $(r=0.84, \mathrm{p} \leq 0.05)$. The accumulation of malic acid improved the fermentability of plant biomass, causing a rapid acidification of the feed to $\mathrm{pH}$ 4.4-4.3 due to the introduced preparation of lactic acid bacteria Biotrof. This method improved the biochemical parameters of the feed, contributing to a decrease in the butyric acid level, however, it did not lead to a noticeable improvement in the preservation of nutrients and an increase in the energy nutritional value of the dry matter of the obtained haylage due to the favorable fermentation process in dried alfalfa biomass. Acceleration of the acidification of the dried mass with the Biotrof preparation did not have a significant effect on the reduction of ammonia formation during fermentation. Staphylococcus arlettae, Salmonella subterranea, Streptococcus gordonii, and Enterococcus cecorum capable of causing diseases in humans and animals, survived up to 4-14 days of storage in haylage without additives. In this regard, the stored haylage, if technological disturbances occur, may contain pathogens of farm animals, therefor, antimicrobial biologicals are required for conservation. Therefore, the main effect of the Biotrof application was reduced only to an improvement in the biochemical parameters of the feed without leading to a noticeable increase in its preservation.

Keywords: alfalfa, haylage, proteolysis, microbiota, biologicals, lactobacteria, acidification, feed quality, NGS sequencing, quantitative PCR.

\section{REFERENCES}

1. Proizvodstvo grubykh kormov (v 2-kh knigakh). Kniga 1. Pod redaktsiei D. Shpaara [Coarse feed 
preparation (in 2 books). Book 1]. Torzhok, 2002 (in Russ.).

2. McKersie B.D. Effect of $\mathrm{pH}$ on proteolysis in ensiled legume forage. Agronomy Journal, 1983, 77, 1: 81-86.

3. Tao L., Guo X.S., Zhou H., Undersander D.J., Nandety A. Short communication: Characteristics of proteolytic activities of endo- and exopeptidases in alfalfa herbage and their implications for proteolysis in silage. Journal of Dairy Science, 2012, 95(8): 4591-4595 (doi: 10.3168/jds.20125383).

4. Pobednov Yu.A., Kosolapov V.M. Biology of alfalfa silage making (review). Agricultural Biology [Sel'skokhozyaistvennaya biologiya], 2018, 53(2): 258-269 (doi: 10.15389/agrobiology.2018.2.258eng).

5. Khimiya i biokhimiya bobovykh rastenii. Pod redaktsiei M.N. Zaprometova [Chemistry and biochemistry of legumes. M.N. Zaprometov (ed.)]. Moscow, 1986 (in Russ.).

6. Pobiednow J.A., Achlamow J.D., Otroszko S.A., Szewcow A.W. Technologie konserwacji pasz objçtościowych. In: Efektywne sposoby produkcji pasz objętościowych na łakach i pastwiskach $w$ zróżnicowanych warunkach siedliskowych Polski i Rosji. J. Barszczewski, W.M. Kosolapow (eds.). Falenty, 2016: 252-283.

7. Kurna€v O.M. Kormi i kormovirobnitstvo. Mizhvidomchii tematichnii naukovii zbirnik. Vinnitsya, 66: 274-280.

8. Whiter A.G., Kung L. Jr. The effect of dry or liquid application of Lactobacillus plantarum MTDI on the fermentation of alfalfa silage. Journal of Dairy Science, 2001, 84(10): 2195-2202 (doi: 10.3168/jds.S0022-0302(01)74666-8).

9. Pobednov Yu.A. Kormoproizvodstvo, 2012, 8: 37-38 (in Russ.).

10. Zheng M., Niu D., Zuo S., Mao P., Meng L., Xu C. The effect of cultivar, wilting and storage period on fermentation and the clostridial community of alfalfa silage. Italian Journal of Animal Science, 2018, 17, 2: 336-346. (doi: 10.1080/1828051X.2017.1364984)

11. Zafren S.Ya. Tekhnologiya prigotovleniya kormov [The technology of manufacturing forages]. Moscow, 1977 (in Russ.).

12. Chukanov N.K., Popenko A.K. Mikrobiologiya konservirovaniya trudnosilosuemykh rastenii [Microbiology of hard-to-harvest plant conservation]. Alma-Ata, 1986 (in Russ.).

13. Eikmeyer F.G., Köfinger P., Poschenel A., Jünemann S., Zakrzewski M., Heinl S., Mayrhuber E., Grabherr R., Pühler A., Schwab H., Schlüter A. Metagenome analyses reveal the influence of the inoculant Lactobacillus buchneri CD034 on the microbial community involved in grass ensiling. Journal of Biotechnology, 2013, 167(3): 334-343 (doi: 10.1016/j.jbiotec.2013.07.021).

14. Ni K., Minh T.T., Tu T.T., Tsuruta T., Pang H., Nishino N. Comparative microbiota assessment of wilted Italian ryegrass, whole crop corn, and wilted alfalfa silage using denaturing gradient gel electrophoresis and next-generation sequencing. Applied Microbiology and Biotechnology, 2017, 101(4): 1385-1394 (doi: 10.1007/s00253-016-7900-2).

15. Savoie P., Jofriet J.C. Silage storage. In: Silage science and technology, Vol. 42. D.R. Buxton, R.E. Muck, J.H. Harrison (eds.). Madison, 2015: 405-467 (doi: 10.2134/agronmonogr42.c9).

16. Principles and applications of soil microbiology. D. Sylvia, J.J. Fuhrmann, P.G. Hartel, D.A. Zuberer (eds.). Pearson Prentice Hall Upper Saddle River, N.J., 2005.

17. Iyldyrym E.A. Teoreticheskie i eksperimental'nye osnovy mikrobiologicheskoi bezopasnosti konservirovannykh kormov dlya zhvachnykh sel'skokhozyaistvennykh zhivotnykh. Doktorskaya dissertatsiya [Theoretical and experimental bases of microbiological safety of canned food for ruminant farm animals. DSc Thesis]. Dubrovitsy, 2019 (in Russ.).

18. Zubrilin A.A., Mishustin E.M. Silosovanie kormov (teoriya voprosa) [Feed silage - theoretical aspects]. Moscow, 1958 (in Russ.).

19. Yakushkina N.I., Bakhtenko E.Yu. Fiziologiya rastenii [Plant physiology]. Moscow, 2004 (in Russ.).

20. Kuperman I.A., Khitrovo E.V. Dykhatel'nyi gazoobmen kak element produktivnogo protsessa rastenii [Respiratory gas exchange as an element of the productive process in plants]. Novosibirsk, 1977 (in Russ.).

21. Eprintsev A.T. Malatdegidrogenaznaya i akonitaznaya fermentnye sistemy vysshikh rastenii: fiziologo-biokhimicheskaya kharakteristika, regulyatsiya $i$ rol' $v$ adaptatsii $k$ faktoram vneshnei sredy. Avtoreferat doktorskoi dissertatsii [Malate dehydrogenase and aconitase enzyme systems of higher plants: physiological and biochemical characteristics, regulation and role in adaptation to environmental factors. DSc Thesis]. Voronezh, 1991 (in Russ.).

22. Evglevskii A.A., Ryzhkova G.F., Evglevskaya E.P., Vanina N.V., Mikhailova I.I., Denisova A.V., Eryzhenskaya N.F. Vestnik Kurskoi gosudarstvennoi sel'skokhozyaistvennoi akademii, 2013, 9: 6769 (in Russ.).

23. Kheldt G.-V. Biokhimiya rastenii /Per. s angl. M.A. Breiginoi, T.A. Vlasovoi, M.V. Titovoi, V.Yu. Shtratnikovoi [Plant biochemistry]. Moscow, 2014 (in Russ.).

24. Yahaya M.S., Kimura A., Harai J., Nguyen H.V., Kawai M., Takahashi J., Matsuoka S. Evaluation of structural carbohydrates losses and digestibility in alfalfa and orchard grass during 
ensiling. Asian-Australasian Journal of Animal's Sciences, 2001, 14(12): 1701-1704 (doi: 10.5713/ajas.2001.1701).

25. Li X., Tian J., Zhang Q., Jiang Y., Wu Z., Yu Z. Effect of mixing red clover with alfalfa at different ration on dynamics of proteolysis and protease activities during ensiling. Journal of Dairy Science, 2018, 101(10): 8954-8964 (doi: 10.3168/jds.2018-14763).

26. Maevskii E.I., Grishina E.V. Biomeditsinskii zhurnal, 2017, 18(2): 50-80 (in Russ.).

27. Ding W.R., Long R.J., Guo X.S. Effects of plant enzyme inactivation or sterilization on lipolysis and proteolysis in alfalfa silage. Journal of Dairy Science, 2013, 96(4): 2536-2543 (doi: 10.3168/jds.2012-6438).

28. Kim M., Singh D., Lai-Hoe A., Go R., Rahim R.A., Ainuddin A.N., Chun J., Adams J.M. Distinctive phyllosphere bacterial communities in tropical trees. Microbial Ecology, 2012, 63(3): 674-681 (doi: 10.1007/s00248-011-9953-1).

29. Kielak A.M., Barreto C.C., Kowalchuk G.A., van Veen J.A., Kuramae E.E. The ecology of Acidobacteria: moving beyond genes and genomes. Frontiers in Microbiology, 2016, 7: 744 (doi: 10.3389/fmicb.2016.00744).

30. Fierer N., Bradford M.A., Jackson R.B. Toward an ecological classification of soil bacteria. Ecology, 2007, 88(6): 1354-1364 (doi: 10.1890/05-1839).

31. McAllister T.A., Dunière L., Drouin P., Xu S., Wang Y., Munns K., Zaheer R. Silage review: Using molecular approaches to define the microbial ecology of silage. Journal of Dairy Science, 2018, 101(5): 4060-4074 (doi: 10.3168/jds.2017-13704).

32. Mak-Donal'd P. Biokhimiya silosa. M., 1985.

33. Filatov I.I., Kuznetsova T.T., Safronova L.G. Sibirskii vestnik sel'skokhozyaistvennoi nauki, 1978, 5: 44-47 (in Russ.).

34. Tarakanov B.V. Metody issledovaniya mikroflory pishchevaritel'nogo trakta sel'skokhozyaistvennykh zhivotnykh i ptitsy [Microflora of the digestive tract of farm animals and poultry: microbiology techniques]. Moscow, 2006 (in Russ.).

35. Il'ina L.A. Izuchenie mikroflory rubtsa krupnogo rogatogo skota na osnove molekulyarno-biologicheskogo metoda T-RFLP s tsel'yu razrabotki sposobov ee optimizatsii. Kandidatskaya dissertatsiya [T-RFLP study of the cattle rumen microflora to optimize its composition. PhD Thesis]. Dubrovitsy, 2012 (in Russ.).

36. Rodriguez-Castaco G.P., Dorris M.R., Liu X., Bolling B.W., Acosta-Gonzalez A., Rey F.E. Bacteroides thetaiotaomicron starch utilization promotes quercetin degradation and butyrate production by Eubacterium ramulus. Frontiers in Microbiology, 2019, 10: 1145 (doi: 10.3389/fmicb.2019.01145).

37. Dinakaran V., Shankar M., Jayashree S., Rathinavel A., Gunasekaran P., Rajendhran J. Genome sequence of Staphylococcus arlettae strain CVD059, isolated from the blood of a cardiovascular disease patient. Journal of Bacteriology, 2012, 194(23): 6615-6616 (doi: 10.1128/JB.01732-12).

38. Shelobolina E.S., Sullivan S.A., O'Neill K.R., Nevin K.P., Derek R. Isolation, characterization, and U(VI)-reducing potential of a facultatively anaerobic, acid-resistant bacterium from low-pH, nitrate- and U(VI)-contaminated subsurface sediment and description of Salmonella subterranea $\mathrm{sp}$. nov. Applied and Environmental Microbiology, 2004, 70(5): 2959-2965 (doi: 10.1128/AEM.70.5.29592965.2004).

39. Dave A.M., Ratnaraj F., Velagapudi M., Krishnan M., Gujjula N.R., Foral P.A., Preheim L. Streptococcus gordonii empyema: a case report and review of empyema. Cureus, 2017, 9(4): e1159 (doi: 10.7759/cureus.1159).

40. Pan Y., An H., Fu T., Zhao S., Zhang C., Xiao G., Zhang J., Zhao X., Hu G. Characterization of Streptococcus pluranimalium from a cattle with mastitis by whole genome sequencing and functional validation. BMC Microbiology, 2018, 18(1): 182 (doi: 10.1186/s12866-018-1327-0).

41. Jung A., Metzner M., Ryll M. Comparison of pathogenic and non-pathogenic Enterococcus cecorum strains from different animal species. BMC Microbiology, 2017, 17(1): 33 (doi: 10.1186/s12866-0170949-y).

42. Simu K., Hagström A. Oligotrophic bacterioplankton with a novel single-cell life strategy. Applied and Environmental Microbiology, 2004, 70(4): 2445-2451 (doi: 10.1128/AEM.70.4.2445-2451.2004).

43. Pobednov Yu.A., Mamaev A.A., Ivanova M.S., Yurtaeva K.E. Zhivotnovodstvo i kormoproizvodstvo, 2018, 101, 1: 213-220 (in Russ.).

44. Mohammed R., Stevenson D.M., Beauchemin K.A., Muck R.E., Weimer P.J. Changes in ruminal bacterial community on following feeding of alfalfa silage in occulated with a commercial silage inoculant. Journal of Dairy Science, 2012, 95(1): 328-339 (doi: 10.3168/jds.2011-4492). 